\title{
Insulin-like growth factor-I receptor activity is essential for Kaposi's sarcoma growth and survival
}

\author{
S-B Catrina*,', M Lewitt', C Massambu², A Dricu², J Grünler', M Axelson ${ }^{3}$, P Biberfeld $^{2}$ and K Brismar' \\ 'Department of Molecular Medicine, Diabetes Center Karolinska, Karolinska Hospital, M I:02, Karolinska Institutet, Stockholm, Sweden; \\ ${ }^{2}$ Immunopathology Lab, Karolinska Hospital, MI:02, Karolinska Institutet, Stockholm, Sweden; ${ }^{3}$ Department of Clinical Chemistry, Karolinska Hospital, \\ M I:02, Karolinska Institutet, Stockholm, Sweden
}

\begin{abstract}
Kaposi's sarcoma (KS) is a highly vascular tumour and is the most common neoplasm associated with human immunodeficiency virus (HIV-I) infection. Growth factors, in particular vascular endothelial growth factor (VEGF), have been shown to play an important role in its development. The role of insulin-like growth factors (IGFs) in the pathophysiology of different tumours led us to evaluate the role of IGF system in KS. The IGF-I receptors (IGF-IR) were identified by immunohistochemistry in biopsies taken from patients with different AIDS/HIV-related KS stages and on KSIMM cells (an established KS-derived cell line). Insulin-like growth factor-I is a growth factor for KSIMM cells with a maximum increase of ${ }^{3} \mathrm{H}$-thymidine incorporation of $130 \pm 27.6 \%(P<0.05)$ similar to that induced by VEGF and with which it is additive $(281 \pm 13 \%)(P<0.05)$. Moreover, specific blockade of the receptor (either by $\alpha$ IR3 antibody or by picropodophyllin, a recently described selective IGF-IR tyrosine phosphorylation inhibitor) induced KSIMM apoptosis, suggesting that IGF-IR agonists (IGF-I and -II) mediate antiapoptotic signals for these cells. We were able to identify an autocrine loop essential for KSIMM cell survival in which IGF-II is the IGF-IR agonist secreted by the cells. In conclusion, IGF-I pathway inhibition is a promising therapeutical approach for KS tumours.
\end{abstract}

British Journal of Cancer (2005) 92, |467- |474. doi:| 0.1038/sj.bjc.6602408 www.bjcancer.com

Published online 5 April 2005

(c) 2005 Cancer Research UK

Keywords: Kaposi's sarcoma; IGF-I; IGF-II IGF-IR; VEGF; proliferation; growth factors; apoptosis; picropodophyllin

The development of Kaposi's sarcoma (KS) is characterised by spindle cell (SC) proliferation, inflammatory cell infiltration, neoangiogenesis, oedema and invasiveness. It is the most frequent tumour in AIDS patients and, although antiretroviral therapy seems to improve the prognosis of patients with AIDS-KS tumours, almost all patients eventually develop disseminated disease (Bower et al, 1999). The lack of specific therapy is a driving force towards the identification of possible new therapeutic targets.

Kaposi's sarcoma origin and pathogenesis is still debated. Along with infectious agents such as HIV-1 and HHV-8 (also known as KS-associated herpes virus) (the subject of a recent review (Boshoff and Weiss, 2002)), cytokines and growth factors appear to play an important role in KS development (Ensoli and Sturzl, 1998; Skobe et al, 1999). Vascular endothelial growth factor (VEGF) is suggested to have a central paracrine/autocrine role for tumour growth (Masood et al, 1997). However, blocking VEGF with a specific antibody seems to affect mainly the vascularisation of the tumour rather than the tumour cell behaviour itself (Samaniego et al, 2002). Therefore, a specific alternative approach, which would interfere with tumour proliferation and survival, could be of value for KS therapy. KS cells display not only a dysregulation of the proliferation, but they are also resistant to

\footnotetext{
*Correspondence: Dr S-B Catrina;

E-mail: Sergiu-Bogdan.Catrina@molmed.ki.se

Received II August 2004; revised 10 December 2004; accepted 4 January 2005; published online 5 April 2005
}

apopotosis (Mori et al, 1996; Buttiglieri et al, 2004a). Insulin-like growth factor-I (IGF-I) is an important mitogen and antiapoptotic factor in various tissues. It can act as a systemic hormone or as a local growth factor. The systemic levels of IGF-I are positively influenced mainly by growth hormone $(\mathrm{GH})$ and by nutrition (Yakar et al, 2002). The biological effects of IGF-I are mediated through the activation of IGF-I receptors (IGF-IR) which exhibit the same affinity for IGF-II and can also be activated by high doses of insulin (LeRoith and Roberts Jr, 2003). Experimental and epidemiological evidence highlights the involvement of IGF-I system in different malignancies (Khandwala et al, 2000), as well as an essential role in angiogenesis along with VEGF (Smith et al, 1999). Interference with IGF-IR function in several neoplastic diseases seems to be an attractive pharmaceutical approach especially nowadays when specific and easy-to-deliver compounds are available (LeRoith and Helman, 2004). To our knowledge, no previous studies have addressed the role of IGF-I on KS biology.

In this study, we have used a KS cell line (KSIMM) to evaluate the importance of IGF-I on KS biology. These cells produce highly angiogenic and haemorrhagic tumours when injected in nude mice, mimicking the human disease (Albini et al, 1997). We make the novel observation that IGF-I receptors (IGF-IR) are essential for both proliferation and antiapoptotic signals. Moreover, we identified an autocrine loop essential for KSIMM cell survival, in which IGF-II is the tumoral ligand for IGF-IR. The presence of IGF-IR on the surface of AIDS-KS tumour cells in situ suggests that our experimental observation can be used as a basis for the pharmacological IGF-IR interference for the treatment of patients 
with this disease. In this respect, a novel specific IGF-IR tyrosine phosphorylation blocker, picropodophyllin (PPP), which has shown antitumoral properties in vivo (Girnita et al, 2004), induced apoptosis in KSIMM cells.

\section{MATERIALS AND METHODS}

\section{Materials}

Recombinant human IGF-I was provided by Pharmacia (Stockholm, Sweden), IGF-II was a kind gift from Eli Lily (Indianapolis), VEGF-165 was purchased from R\&D Systems (Abingdon, UK) and human insulin from Novo Nordisk (Denmark). Cell culture reagents were from Gibco (Stockholm, Sweden), ${ }^{3} \mathrm{H}$-thymidine was purchased from NEN Life Sciences Products and scintillation liquid (Ultima Gold) from Perkin-Elmer (Boston, USA). Mouse monoclonal antibody against the $\alpha$ subunit of IGF-IR (2C8), used for immunohistochemistry, and mouse monoclonal-anti-CD34 (endothelial antigen) were from Santa Cruz Biotechnology, Inc. (USA); anti-mouse IgG and peroxidase-linked whole antibody were from Amersham (Uppsala, Sweden), and mouse monoclonal anti-IGF-IR antibody ( $\alpha$ IR 3 ), used for cell culture, was obtained from Oncogene Research Products (Boston, USA). Picropodophyllin was prepared as described previously (Girnita et al, 2004). All other reagents used for immunohistochemistry were from DAKO (Denmark)

\section{Immunohistochemistry for detecting IGF-IR and CD34 expression}

Diagnostic, surgical biopsies of AIDS-related KS lesions from patients in Tanzania (Dept. Pathology, Muhimbili Medical School, Dar El. Salaam) ( $n=8$, four nodular and four patch lesions) were formalin-fixed, embedded in paraffin and sectioned for histopathological and immunohistochemical evaluation. The patients HIV status was evaluated by serology using the Wellcozyme Recombinant anti-HIV-1 ELISA VK56 (Murex Diagnostics, Toronto, Canada). Serial tissue sections were evaluated for IGF-IR and CD34 expression using $\mathrm{ABC}$ immunohistochemistry with an antiavidin enhancement technique (van Gijlswijk et al, 1996). Paraffin sections were deparaffinised, rehydrated and pretreated by microwave heating in citrate buffer, $\mathrm{pH} 6$, and endogenous peroxidase activity blocked by hydrogen peroxide $(3 \%$ for $30 \mathrm{~min}$ ), as described previously (Kaaya et al, 2000). After rinsing and blocking with normal horse serum, serial sections were incubated with anti-IGF-IR or anti-CD34 antibody for $2 \mathrm{~h}$ at $37^{\circ} \mathrm{C}$. This was followed by rinsing and incubation with biotinylated secondary antibody (horse anti-mouse) for $40 \mathrm{~min}$ and another rinsing and incubation with $\mathrm{ABC}$ peroxidase $(30 \mathrm{~min})$. To increase the sensitivity of $\mathrm{ABC}$, a biotinylated antibody against avidin $(30 \mathrm{~min})$ and a second $\mathrm{ABC}$ peroxidase treatment $(30 \mathrm{~min})$ was performed. Bound $A B C$ was visualised by incubation with fresh $3,3^{\prime}$-diamino benzidine (DAB) for 2-10 min. Negative controls using isotype-matched antibody were included and placenta biopsies were used as IGF-IR positive control.

Insulin-like growth factor-I receptor immunostaining in KSIMM cells cultured on chamber slides and fixed in paraformaldehyde (PFA) 4\% in PBS, pH 7.4, was performed using the monoclonal mouse IgG1 antibody at a concentration of $10 \mu \mathrm{g} \mathrm{ml}^{-1}$ as described previously (Catrina et al, 2002). Negative controls using isotypematched IgG were included.

\section{Cell culture}

KSIMM cells, kindly provided by Dr A Albini (Istituto Nazionale per la Ricerca sul Cancro, Genova, Italy), were cultured in DMEM supplemented with $2 \mathrm{~mm}$ L-glutamine, $100 \mathrm{IU} \mathrm{ml}^{-1}$ penicillin and streptomycin and $10 \%$ heat-inactivated bovine serum (FBS) in a humidified atmosphere with $5 \% \quad \mathrm{CO}_{2}$ at $37^{\circ} \mathrm{C}$. Proliferation experiments and MTT assay experiments were carried out in 96well microtest plates (plated at a density of $1 \times 10^{4}$ cells well $^{-1}$ ) with five replicates for each concentration, for FACS analysis in $100 \mathrm{~mm}$ Petri dishes and for TdT-mediated dUTP nick end labelling (TUNEL) assay in chamber slides (Nalge Nunc, Naperville, USA) with duplicates. The experiments were repeated at least three times. At $24 \mathrm{~h}$ following plating, the cells were rinsed once with medium without FBS, serum-starved for $24 \mathrm{~h}$, rinsed again with medium without FBS and incubated with testing substances for the times indicated, as volumes less than $0.01 \%$.

\section{Evaluation of cell proliferation by ${ }^{3} \mathrm{H}$-thymidine incorporation assay}

After $44 \mathrm{~h}$ of incubation with testing substances, $1 \mu \mathrm{Ci}{ }^{3} \mathrm{H}$ thymidine was added to each well. After $4 \mathrm{~h}$, the cells were washed twice with $0.9 \%$ ice-cold $\mathrm{NaCl}$. The cell-associated radioactivity, precipitated with $5 \%$ TCA, was determined by liquid scintillation counting. Results are expressed as a percentage of the control, untreated cells.

\section{MTT assay}

After $44 \mathrm{~h}$ of incubation with PPP or control (DMSO), the number of viable cells was evaluated using the MTT viability assay, as we described previously (Catrina et al, 1999). Briefly, $20 \mu \mathrm{l}$ MTT (3-[4, 5-dimethylthiazol-2-yl]-2, 5-diphenyltetrazolium bromide; thyazolil blue) $\left(5 \mathrm{mg} \mathrm{ml}^{-1}\right)$ in DMEM was added to each well. After $4 \mathrm{~h}$ of incubation, the formazan crystals, produced by viable cells, were dissolved with $100 \mu \mathrm{l} 0.004 \mathrm{~N} \mathrm{HCl}$-isopropyl alcohol for $5 \mathrm{~min}$. The cell survival rate was calculated from the optical density at $570 \mathrm{~nm}$ after subtracting the optical density at $620 \mathrm{~nm}$. Results are expressed as a percentage of the control treated cells.

\section{Evaluation of cell apoptosis}

TdT-mediated dUTP nick end labelling assay and morphological evaluation TdT-mediated dUTP nick end labelling was carried out using a fluorescein-labelled in situ cell death detection kit (Roche, Bromma, Sweden) as described previously (Catrina et al, 2002). Briefly, the cells fixed in PFA were permeabilised with $0.1 \%$ Triton $\mathrm{X}-100$ in $0.1 \%$ sodium citrate solution for $2 \mathrm{~min}$ on ice and $50 \mu \mathrm{l}$ TUNEL reaction reagent/sample was applied over the cells. After $60 \mathrm{~min}$ incubation at $37^{\circ} \mathrm{C}$ in the dark, the slides were examined by fluorescence microscopy. For light microscopy evaluation, the slides were incubated for $30 \mathrm{~min}, 37^{\circ} \mathrm{C}$ with $50 \mu \mathrm{l}$ converter POD in PBS $0.1 \%$ BSA, and exposed to $\mathrm{DAB}$ solution $\left(0.5 \mathrm{mg} \mathrm{m}^{-1}\right)$ (Sigma). Finally, the samples were counterstained with Meyer haematoxylin. The classical morphological apoptosis criteria of nuclear condensation, membrane blebbing and formation of apoptotic bodies combined with TUNEL-positive reaction of the nuclei were used to evaluate, by light microscopy, the apoptotis, which was expressed as an apoptotic index (percentage of apoptotic cells from 500 counted cells).

\section{FACS with annexin V/propidium iodide}

Following incubation with specified substances, cells were trypsinised and then stained with annexin $\mathrm{V}$ and propidium iodide as specified by the manufacturer (R\&D Systems, Oxon, UK) and analysed by flow cytometry. In order to compare the effect of different substances on the survival rate, we generated histograms for annexin $\mathrm{V}$ fluorescence, and positive cells were gated and expressed as percentages from the total number of acquired cells. 
Insulin-like growth factor-I and IGF-II assay in KSIMM cell culture medium

Insulin-like growth factor-I and IGF-II in conditioned KSIMM cultured medium were assayed after HPLC separation from IGFBPs by radioimmunoassay (RIA) using high-affinity antibodies. The IGF-I assay was previously described (Bang et al, 1991) and has a detection limit $0.07 \mathrm{ng} \mathrm{ml}^{-1}$ with intra- and interassay coefficients of variation 4 and $11 \%$. Respectively, IGF-II assay was performed under the same conditions as IGF-I assay, except that IGF-II labelled by the chloramine $\mathrm{T}$ method was used as a tracer and an anti-IGF-II mouse monoclonal antibody (S1F2) was used as first antibody in a final concentration of 1:150000 (Upstate Biotechnology, Lake Placid, NY, USA), and the separation was performed using an anti-mouse IgG (Sac-Cel, IDS Ltd, Boldon, UK). The detection limit was $0.05 \mathrm{ng} \mathrm{ml}^{-1}$, with an intra-assay coefficient of variation of $3 \%$.

The HPLC separation of the IGFs from IGFBPs was performed using a size-exclusion chromatography after incubation for $30 \mathrm{~min}$ at $22^{\circ} \mathrm{C}$ of $50 \mu \mathrm{l}$ conditioned culture medium with $50 \mu \mathrm{l}$ column buffer $(5 \times)$ (acetic acid $0.2 \mathrm{M}$, trimethylamine $0.1 \mathrm{M}$ and Triton X$1000.5 \mathrm{gl}^{-1}, \mathrm{pH} 2.8$ adjusted with sulphuric acid) as described previously (Crawford et al, 1992).

\section{Statistical analysis}

All values are presented as mean \pm s.e. The data were analysed by one-way ANOVA with a Tukey post hoc test; or Kruskall-Wallis one-way analysis of variance with Dunn's method, as appropriate, using SigmaStat v2.03 SPSS Inc.

\section{RESULTS}

\section{Insulin-like growth factor-I receptors are expressed in AIDS-related KS tumours}

The expression of IGF-IR was evaluated in eight cases of AIDSrelated KS tumour biopsies by immunohistochemistry. A large proportion of the KS tumour SCs, identified by morphology and positive immunostaining for $\mathrm{CD} 34$ in serial sections, showed positive staining with the anti-IGF-IR antibody. In addition, most vessels and slit-lining cells, and some infiltrating leucocytes, were positively stained (Figure 1A, B). No significant difference was seen between patch (early) and nodular (late) lesions in the immunostaining pattern (data not shown).

\section{Insulin-like growth factor-I stimulates KSIMM cell proliferation}

The effect of IGF-I on the proliferation of KSIMM cells was investigated using the ${ }^{3} \mathrm{H}$-thymidine incorporation. Insulin-like growth factor-I stimulated the proliferation of KSIMM cells in vitro in a dose-dependent manner by a maximum increase of $130 \pm 27.6 \%$ $\left(P<0.05\right.$ for concentrations higher than $\left.1 \mathrm{ng} \mathrm{ml}^{-1}\right)$ (Figure $\left.2 \mathrm{~A}\right)$. The effect of IGF-I on the proliferation of KSIMM cells was of the same magnitude as VEGF, postulated to be an essential growth factor for KS cells (maximum increase of $151.9+30.5 \% ; P<0.05$ for concentrations higher than $1 \mathrm{ng} \mathrm{ml}^{-1}$ ) (Figure 1B). The combination of $10 \mathrm{ng} \mathrm{ml}^{-1}$ of IGF-I (maximally effective stimulatory concentration) and VEGF $\left(0.1-100 \mathrm{ng} \mathrm{ml}^{-1}\right)$ had an additive effect, increasing the proliferation rate by a maximum of $281 \pm 13 \%(P<0.05)$ (Figure 1B).

\section{The growth-promoting effects of IGF-I on KSIMM cells are mediated by IGF-IR}

To investigate what receptor mediates the effect of IGF-I, we have compared the growth-promoting effect of des $(1-3)$ IGF-I (agonist for IGF-IR, which binds minimally to the IGFBPs) with insulin. Des (1-3) IGF-I stimulates the growth rate of KSIMM cells in a
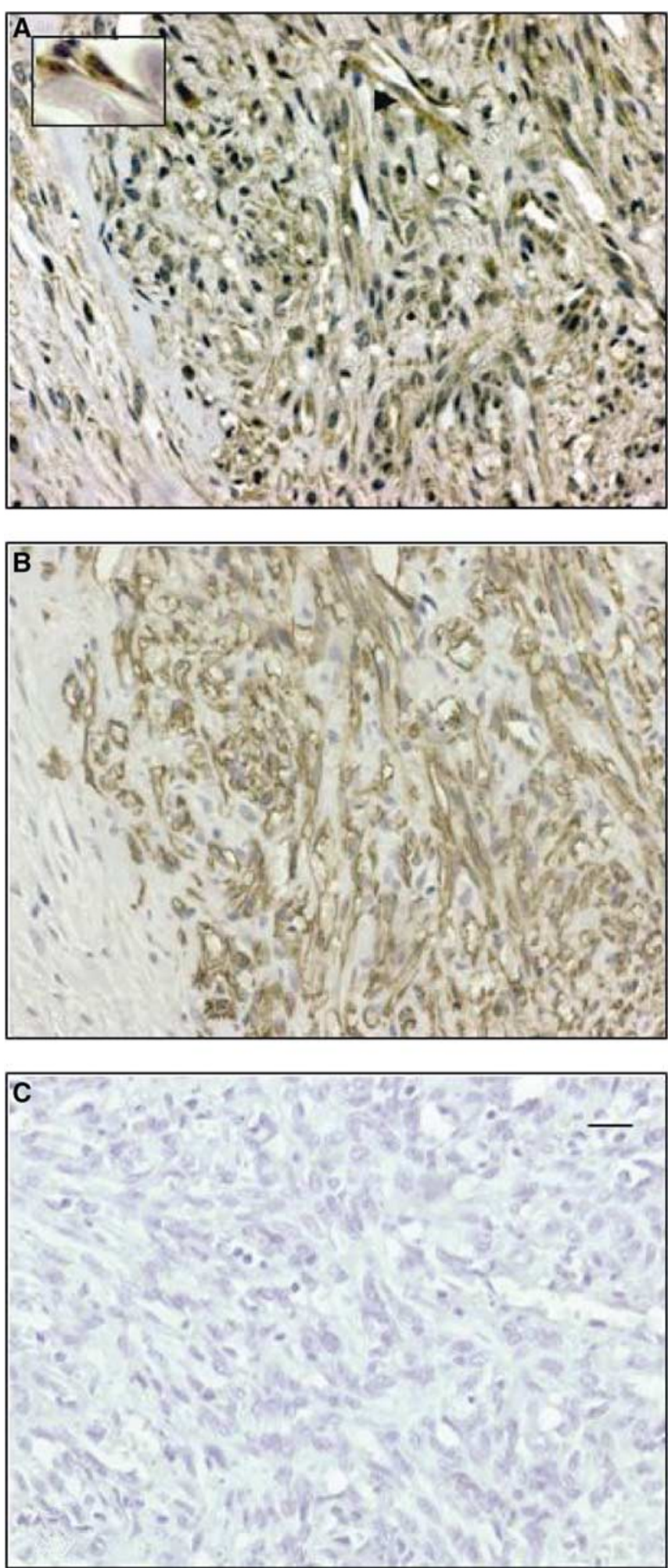

Figure I AIDS-KS biopsies show immunoreactivity for IGF-IR. Serial sections of paraffin-embedded KS biopsies were evaluated for IGF-IR and CD34 expression. (A) Immunohistochemistry for IGF-IR showing reactivity in tumour SCs (small arrow) and some infiltrating leukocytes (long arrow). Original magnification $\times 250$. The inset panel shows IGF-IR reactivity in spindle tumour cells at a higher magnification $(\times 500)$. (B) Immunohistochemistry for CD34 showing reactivity in tumour SCs. (C) Negative control with mouse IgGI.The bar represents $15 \mu \mathrm{m}$. 

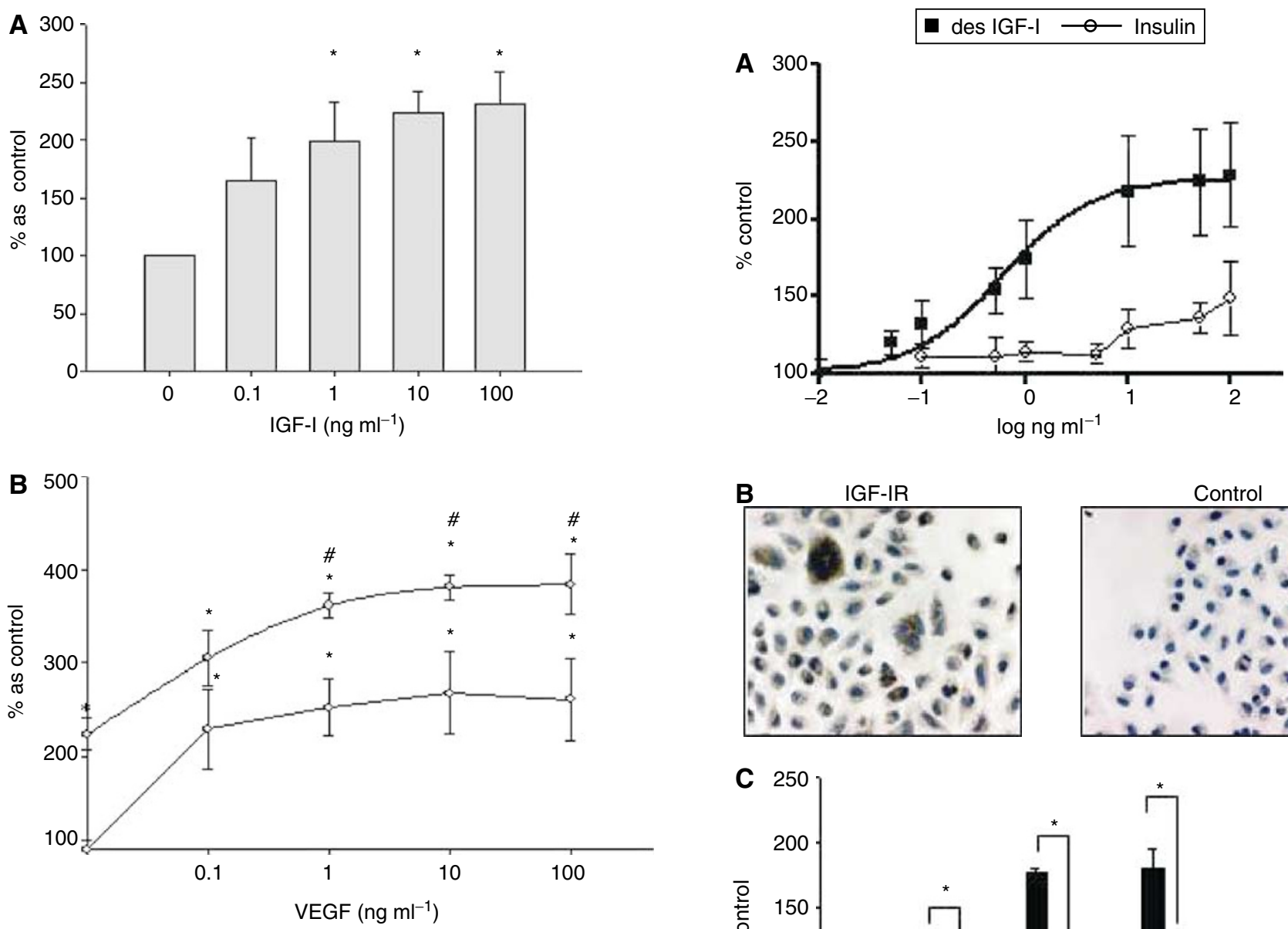

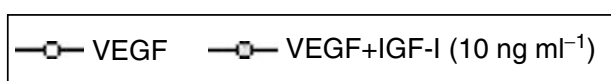

Figure 2 Insulin-like growth factor-l increases in a dose-dependent manner proliferation of KSIMM cells with potency similar to VEGF, with which it has an additive effect. (A) KSIMM cells, starved for $24 \mathrm{~h}$, were exposed to either IGF-I or vehicle for $48 \mathrm{~h}$ when proliferation was assessed by ${ }^{3} \mathrm{H}$-thymidine incorporation. The values represent means \pm s.e.m. from five different experiments $(* P<0.05)$. (B) KSIMM-starved cells were exposed to either VEGF alone $\left(0.1-100 \mathrm{ng} \mathrm{m}^{-1}\right)$ or to the combination of VEGF and $10 \mathrm{ng} \mathrm{ml}^{-1}$ IGF-I. Cell proliferation was assessed by ${ }^{3} \mathrm{H}$-thymidine incorporation after $48 \mathrm{~h}$ incubation. The values represent means \pm s.e.m. from three different experiments ( ${ }^{*} P<0.05$ as control, ${ }^{\#} P<0.05$ as equivalent VEGF concentration).

dose-response manner with an $\mathrm{EC}_{50}$ around $0.58 \mathrm{ng} \mathrm{ml}^{-1}$ far more potent than insulin that, at $100 \mathrm{ng} \mathrm{ml}^{-1}$, reaches less then $50 \%$ of the maximal effect of IGF-I. This suggests that IGF-IR is the mediator of IGF-I effects on KSIMM cells (Figure 3A). The presence of this receptor in KSIMM cells was further demonstrated by immunohistochemistry. As presented in Figure 3B, KSIMM cells are specifically immunopositive for the $\alpha$ subunit of IGF-IR with both cytoplasmic and pericellular patterns. The functional involvement of these receptors as mediators of the IGF-I growthpromoting effect was demonstrated by the complete abolishment of the IGF-I effect when the cells were co-incubated with $\alpha$ IR3 monoclonal blocking antibody (Flier et al, 1986) (Figure 3C).

\section{Insulin-like growth factor-I receptor mediates antiapoptotic signals in KSIMM cells}

The profound inhibition of ${ }^{3} \mathrm{H}$-thymidine incorporation in KSIMM cells after specific blockade of the IGF-IR prompted us to
B
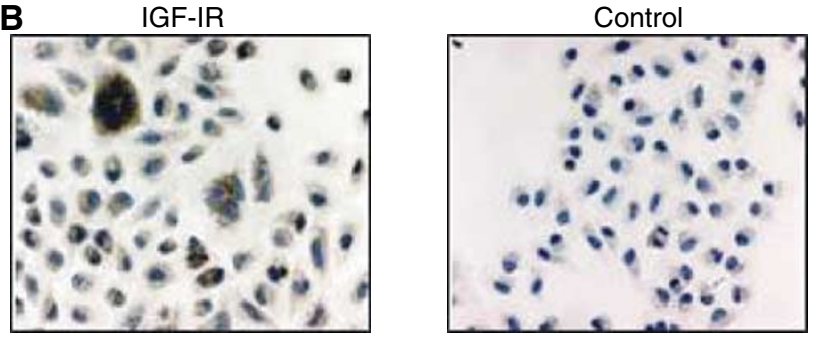

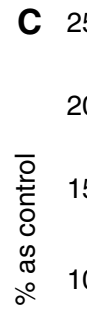

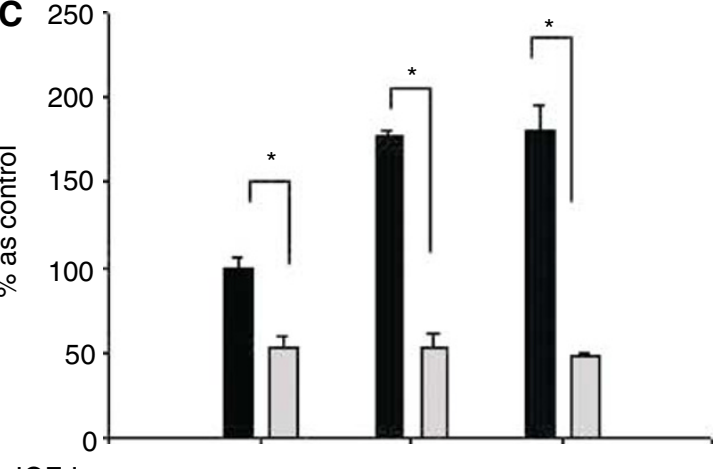

IGF-I

(ng ml-1)

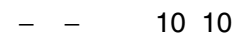

100100

$\alpha \operatorname{IR3}$

$\left(1 \mu \mathrm{g} \mathrm{ml}^{-1}\right)$

Figure 3 Insulin-like growth factor-I growth-promoting effect on KSIMM cells is mediated by IGF-IR. (A) KSIMM cells, starved for $24 \mathrm{~h}$, were exposed to either des $(I-3)$ IGF-I or insulin for $48 \mathrm{~h}$ when proliferation was assessed by ${ }^{3} \mathrm{H}$-thymidine incorporation. The values represent mean$\mathrm{s} \pm$ s.e.m. from three different experiments. (B) Immunohistochemical identification of IGF-IR in KSIMM. The left panel shows intra and pericellular positivity of the KSIMM cells for IGF-IR. The right panel shows the negative control with mouse IgGI. (C) KSIMM cells, starved for $24 \mathrm{~h}$, were exposed to IGF-I alone (I0 and $100 \mathrm{ng} \mathrm{ml}^{-1}$ ) or in combination with the specific blocking antibody for IGF-IR, $\alpha$ IR3. After $48 \mathrm{~h}$, proliferation was assessed by ${ }^{3} \mathrm{H}$-thymidine incorporation. The values represent means \pm s.e.m. from three experiments $(* P<0.05)$.

investigate a potential antiapoptotic effect mediated through IGF-IR. Treatment of the cells with IGF-I had no significant effect on the apopotic rate of KSIMM cells (apoptotic index $1.3 \pm 0.3$ vs $3.8 \pm 0.7 \%$ in control), but blocking IGF-IR with $\alpha$ IR3 monoclonal antibody induced apoptosis. This effect was documented both by the positivity of KSIMM cells for Annexin V (Figure 4A) and by typical apoptotic morphology and TUNEL-positive staining (Figure 4B) after treatment with $\alpha$ IR3 (apoptotic index 21.8 \pm 0.7 


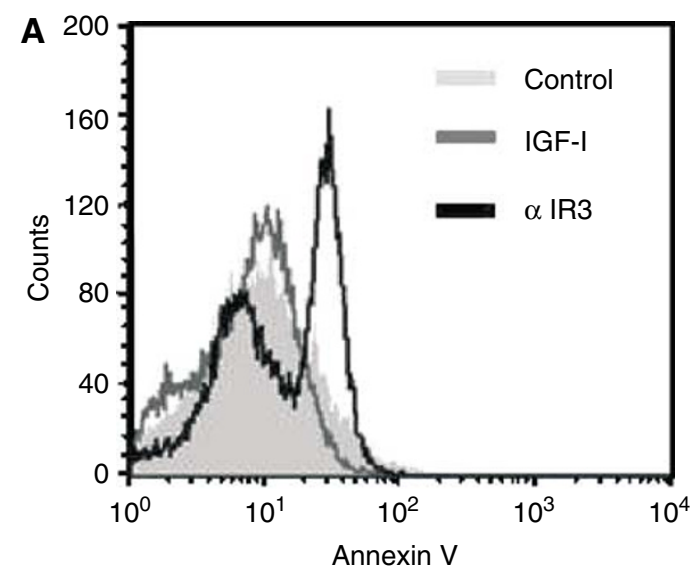

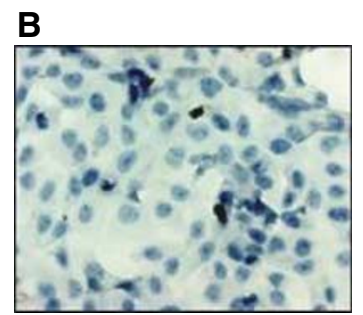

Control

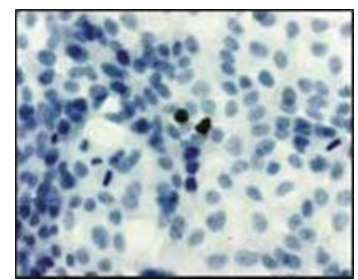

IGF-I

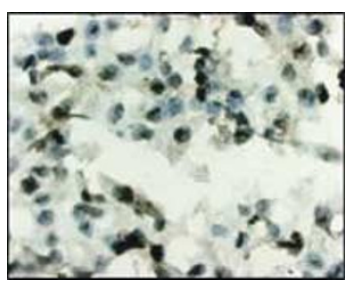

$\alpha \operatorname{IR3}$

Figure 4 Insulin-like growth factor-I receptor mediates antiapoptotic signals for KSIMM cells. (A) KSIMM cells were treated, after starving for $24 \mathrm{~h}$, with either IGF-I $\left(100 \mathrm{ng} \mathrm{ml}^{-9}\right), \alpha$ IR3 $\left(\left.\mathrm{I} \mathrm{mg} \mathrm{ml}\right|^{-1}\right)$ or vehicle for $24 \mathrm{~h}$ and analysed by FACS for annexin $\mathrm{V}$ binding. (B) KSIMM cells were starved for $24 \mathrm{~h}$ and then treated with either IGF-I $\left(I 00 \mathrm{ng} \mathrm{ml}^{-1}\right), \alpha$ IR3 $\left(\mathrm{I} \mu \mathrm{g} \mathrm{ml}^{-1}\right)$ or vehicle for $48 \mathrm{~h}$, fixed in PFA $4 \%$ and then stained for TUNEL and counterstained with Meyer haematoxylin (magnification $\times 500)$.

vs $3.8 \pm 0.7 \%$ in control $)(P<0.001)$. No changes in the number of propidium iodide cells were observed following treatment, confirming the specific proapoptotic effect of IGF-IR blocking.

\section{Insulin-like growth factor-II is the endogenous agonist of an autocrine loop in KSIMM cells}

Specific blocking of IGF-IR resulted in decreased spontaneous ${ }^{3} \mathrm{H}$-thymidine incorporation, as well as induction of apoptosis, suggesting the presence of an autocrine loop essential for both proliferation and survival of these tumoral cells. Thus, we measured the putative ligands for IGF-IR (IGF-I and IGF-II) in KSIMM conditioned media after separation from IGFBPs. Insulinlike growth factor-II has been detected in $72 \mathrm{~h}$ conditioned media at a concentration of $4.1 \mathrm{ng} \mathrm{ml}^{-1}$, while IGF-I was under the detection limit of our assay. As expected, exogenous IGF-II had the same growth-promoting effect as IGF-I on KSIMM cells, with a maximum ${ }^{3} \mathrm{H}$-thymidine incorporation of $157 \pm 21 \%(P<0.05)$.

\section{Picropodophyllin, a specific inhibitor of IGF-IR activity, induces apoptosis in KSIMM cells}

The presence of IGF-IR in the tumour specimens from patients with AIDS-KS coupled with the essential functional role of the IGF-IR in KSIMM biology determined us to investigate the effect of PPP, a new, specific IGF-IR tyrosine kinase inhibitor, which has been shown to have antitumoral proprieties in vivo (Girnita et al, 2004). Treatment of KSIMM cells with PPP induced a dosedependent cell death with an $\mathrm{IC}_{50}$ at $95 \mathrm{~nm}$ (Figure 5A), in the range reported for other IGF-IR-positive tumours (Girnita et al, 2004). Treatment of KSIMM cells with $100 \mathrm{nM}$ PPP induced apoptosis as documented by Annexin V positivity (Figure 5B) and by typical apoptotic morphological cell appearance and positive immunostaining for TUNEL (Figure 5C) $(22.1 \pm 1.5$ vs $1.3 \pm 0.5 \%$ in controltreated cells) $(P<0.001)$.

\section{DISCUSSION}

KS is the leading cause of cancer death in areas with endemic AIDS (Parkin et al, 1999). Even though highly active antiretroviral therapy (HAART) has led to a decrease of the KS tumour burden, AIDS patients are still at high risk of developing KS when they discontinue HAART or when the therapy is not available. Developing a therapy specific to the tumour cell biology is imperative for these patients.

Interference with growth factors of importance in KS biology is a logical approach which has already been successful in different malignancies (for a review, see Shawver et al, 2002). Here, we show the presence of the IGF-IR in biopsies taken from patients with AIDS/HIV-related KS, and further demonstrate that the IGF system is essential for cell growth and for mediating antiapoptotic signals in a KS cell line (KSIMM) that has the characteristics of the KS SCs and produce large highly vascularised tumours when injected s.c. in nude mice (Albini et al, 1997). Moreover, we suggest that PPP, a small molecule that specifically interferes with IGF-IR function, is a potential effective therapy.

Insulin-like growth factor-I receptor was found in all the KS tumours studied. No clear difference in IGF-IR cell expression between early and late KS stages was observed, suggesting a constant IGF-IR expression during characteristic multistage development of KS tumours.

The relevance of the functional role of these receptors in KS biology was further demonstrated in KSIMM cells where exogenous IGF-I induced a dose-dependent stimulation of cell proliferation. Insulin-like growth factor-I has been shown to be a growth factor for different tumours and prospective epidemiological data suggested that high circulating levels of IGF-I confer increased risk for different solid tumours (reviewed by LeRoith and Roberts Jr, 2003). For KSIMM cells, IGF-I had the same growth-promoting potency as VEGF, which is postulated to be one of the most important growth factors for KS tumours (Arasteh and 

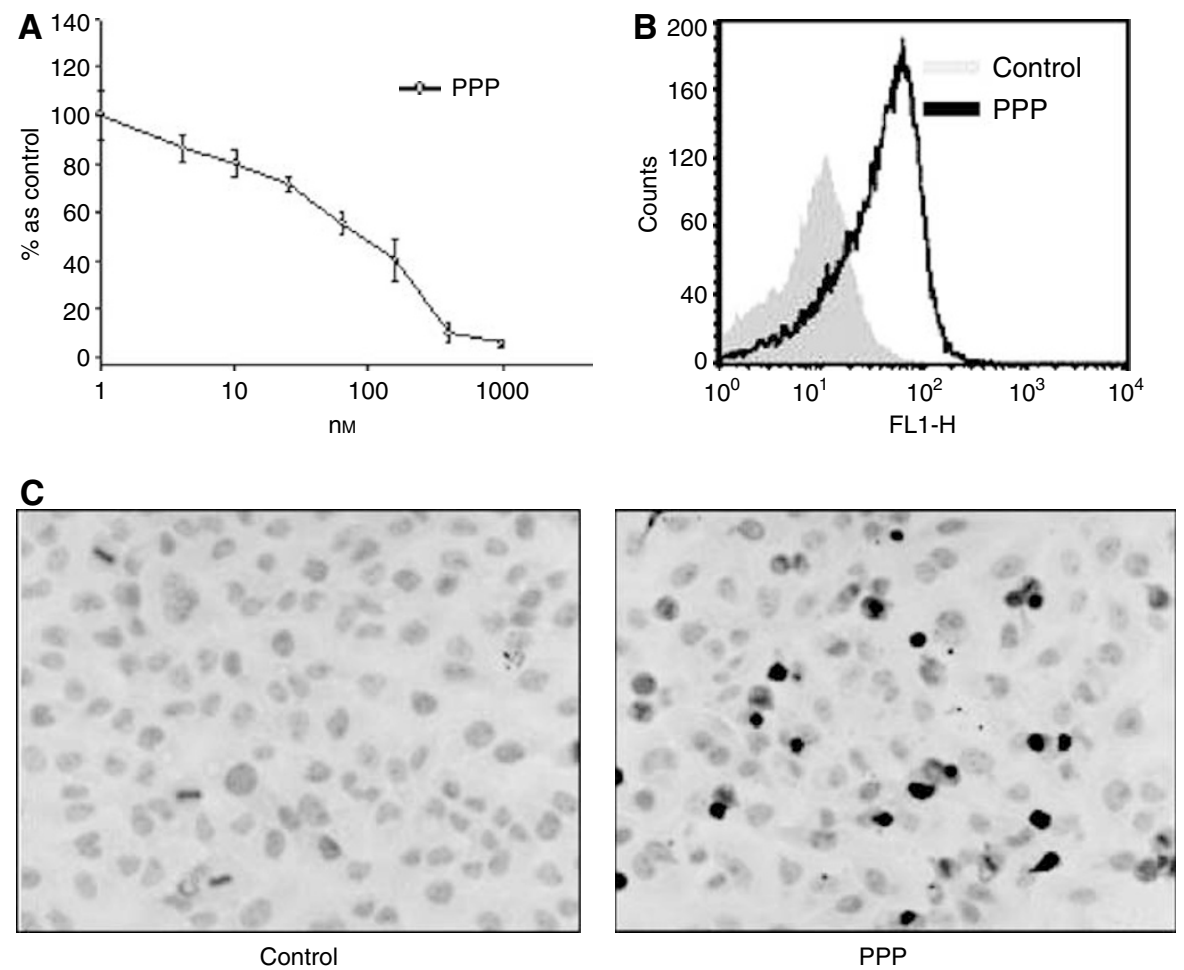

Figure 5 Picropodophyllin, a specific inhibitor of IGF-IR activity, induces apoptosis in KSIMM cells. (A) KSIMM cells were treated with different concentrations of PPP for $48 \mathrm{~h}$ and subjected to MTT assay for the last $4 \mathrm{~h}$. (B) KSIMM cells were treated, after starving for $24 \mathrm{~h}$, with PPP (I $\mu \mathrm{g} \mathrm{ml}^{-1}$ ) or vehicle for $24 \mathrm{~h}$ and analysed by FACS for annexin $\mathrm{V}$ binding. (C) KSIMM cells were starved for $24 \mathrm{~h}$ and then treated with PPP $\left(\mathrm{I}\right.$ mg $\left.\mathrm{ml}^{-1}\right)$ or vehicle for $48 \mathrm{~h}$, fixed in PFA $4 \%$ and then stained for TUNEL and counterstained with Meyer haematoxylin (magnification $\times 500$ ).

Hannah, 2000). Furthermore, IGF-I and VEGF have an additive effect on the KSIMM proliferation rate, which suggests that these two growth factors may act at least in part independently to promote growth. Vascular endothelial growth factor and IGF-I cellular pathways have been reported to either act independently (Hellstrom et al, 2001) or to interact (Smith et al, 1999) in normal endothelial cells. The relationship between VEGF and IGF-I signalling pathways including those involved in cell survival in $\mathrm{KS}$ is the focus of ongoing studies.

Both IGF-IR ligands (IGF-I and IGF-II) have high affinity for IGFBPs, molecules that can compete with their binding to the receptor. Thus, to investigate the potential receptor involved in IGF effect on KSIMM cells, we have used des(1-3)-IGF-I, a full agonist for IGF-IR that binds minimally to IGFBPs (Clemmons et al, 1992).

The effect of IGF-I on KSIMM cells is mediated through IGF-IR. This is suggested by the higher potency of des(1-3)-IGF-I as compared to insulin, as well as the complete abolition of the IGF-I effect through IGF-IR-blocking antibody ( $\alpha$ IR3). Moreover, we demonstrated that both KSIMM cells as well as KS tumours express IGF-1R. Even though hybrid receptors with insulin cannot be excluded (Pandini et al, 2002), the effect of PPP (specific blocker of the beta subunit of IGF-IR (Girnita et al, 2004)) on KSIMM apoptosis suggests that the IGF-IR is the main mediator of IGF system on these cells. The decrease of ${ }^{3} \mathrm{H}$-thymidine incorporation in KSIMM cells after treatment with the IGF-IRblocking antibody $\alpha$ IR3 powerfully suggested the presence of an autocrine loop in these cells. We have in consequence analysed the secretion of both IGF-I and IGF-II by KSIMM cells because both are equally potent ligands for these receptors. Both IGF-I and IGF-II mRNA expression have been documented previously in AIDS-KS cultured cells (Weich et al, 1991) but, to our knowledge, there is no previous report on their secretion in KS cells. To avoid the known interferences of IGFBPs with IGF-I and IGF-II assays, which could give false-positive results, we have first separated them by HPLC. We were able to detect IGF-II but not IGF-I in the conditioned medium. The presence of the IGF-II as member of the endogenous IGF system is not surprising. There is clear evidence of its upregulation in different tumours (Zhang et al, 1997).

We were able to show that the autocrine loop plays an essential role for protecting the KSIMM from apoptosis. This was demonstrated by blocking the IGF-IR in two ways: by using $\alpha$ IR3 (a specific blocking antibody) or by using PPP (specific blocker of the beta subunit of IGF-IR (Girnita et al, 2004)). Exposure of the KSIMM cells to either of these compounds induced apoptosis as demonstrated by both externalisation of phosphatidylserine, TUNEL staining and typical apoptotic morphological changes. We did not observe any significant difference in the apoptosis rate after treatment with IGF-I, which is in line with the reported low spontaneous apoptosis rate of these cells (Buttiglieri et al, 2004b).

In addition to autocrine sources, it may be that KS tumours are stimulated by endocrine IGFs from the circulation. Albini et al (1999) made the observation that the in vivo administration of somatostatin decreases the development of KS-like lesions in mice inoculated with KSIMM cells, despite an absence of somatostatin receptors on the tumoral cell surface. In the light of our data on the effect of IGF-I in these cells, we speculate that somatostatin, by inhibiting pituitary GH release, may also have had an antitumoral effect via a decrease in endocrine IGF-I, as it was demonstrated for other tumors (Wu et al, 2003).

Numerous attempts have been made to block the IGF system for treatment of tumours (reviewed by Surmacz, 2003) but most of the methods had different problems as lack of specificity, difficulty of drug delivery, etc. One of the most promising approach is to use 
specific small molecules that inhibit IGF-IR tyrosine kinase (LeRoith and Helman, 2004). In this light, we have also tested the effect of PPP, which has been shown to be a potent and specific inhibitor of the IGF-IR tyrosine kinase (Girnita et al, 2004). Treatment of the KSIMM cells with PPP induced a dose-dependent apoptosis in the same dose range reported for other IGF-IRpositive cells. We would like to point out that the compound is active even in the presence of FCS, which shows that blocking the IGF system overrides the survival signals from other factors.

\section{REFERENCES}

Albini A, Florio T, Giunciuglio D, Masiello L, Carlone S, Corsaro A, Thellung S, Cai T, Noonan DM, Schettini G (1999) Somatostatin controls Kaposi's sarcoma tumor growth through inhibition of angiogenesis. FASEB J 13: 647-655

Albini A, Paglieri I, Orengo G, Carlone S, Aluigi MG, DeMarchi R, Matteucci C, Mantovani A, Carozzi F, Donini S, Benelli R (1997) The beta-core fragment of human chorionic gonadotrophin inhibits growth of Kaposi's sarcoma-derived cells and a new immortalized Kaposi's sarcoma cell line. AIDS 11: 713-721

Arasteh K, Hannah A (2000) The role of vascular endothelial growth factor (VEGF) in AIDS-related Kaposi's sarcoma. Oncologist 5(Suppl 1): 28-31

Bang P, Eriksson U, Sara V, Wivall IL, Hall K (1991) Comparison of acid ethanol extraction and acid gel filtration prior to IGF-I and IGF-II radioimmunoassays: improvement of determinations in acid ethanol extracts by the use of truncated IGF-I as radioligand. Acta Endocrinol (Copenh) 124: 620-629

Boshoff C, Weiss R (2002) AIDS-related malignancies. Nat Rev Cancer 2: $373-382$

Bower M, Fox P, Fife K, Gill J, Nelson M, Gazzard B (1999) Highly active anti-retroviral therapy (HAART) prolongs time to treatment failure in Kaposi's sarcoma. AIDS 13: 2105-2111

Buttiglieri S, Deregibus MC, Bravo S, Cassoni P, Chiarle R, Bussolati B, Camussi G (2004a) Role of $\operatorname{Pax} 2$ in apoptosis resistance and proinvasive phenotype of Kaposi's sarcoma cells. J Biol Chem 279: 4136-4143

Buttiglieri S, Deregibus MC, Bravo S, Cassoni P, Chiarle R, Bussolati B, Camussi G (2004b) Role of Pax2 in apoptosis resistance and proinvasive phenotype of Kaposi's sarcoma cells. J Biol Chem 279: 4136-4143

Catrina AI, Ulfgren AK, Lindblad S, Grondal L, Klareskog L (2002) Low levels of apoptosis and high FLIP expression in early rheumatoid arthritis synovium. Ann Rheum Dis 61: 934-936

Catrina SB, Catrina AI, Sirzen F, Griffiths W, Bergman T, Biberfeld P, Coculescu M, Mutt V (1999) A cytotoxic, apoptotic, low-molecular weight factor from pineal gland. Life Sci 65: $1047-1057$

Clemmons DR, Dehoff ML, Busby WH, Bayne ML, Cascieri MA (1992) Competition for binding to insulin-like growth factor (IGF) binding protein-2, 3, 4, and 5 by the IGFs and IGF analogs. Endocrinology 131: $890-895$

Crawford BA, Martin JL, Howe CJ, Handelsman DJ, Baxter RC (1992) Comparison of extraction methods for insulin-like growth factor-I in rat serum. J Endocrinol 134: 169-176

Ensoli B, Sturzl M (1998) Kaposi's sarcoma: a result of the interplay among inflammatory cytokines, angiogenic factors and viral agents. Cytokine Growth Factor Rev 9: 63-83

Flier JS, Usher P, Moses AC (1986) Monoclonal antibody to the type I insulin-like growth factor (IGF-I) receptor blocks IGF-I receptormediated DNA synthesis: clarification of the mitogenic mechanisms of IGF-I and insulin in human skin fibroblasts. Proc Natl Acad Sci USA 83: $664-668$

Garcia-Echeverria C, Pearson MA, Marti A, Meyer T, Mestan J, Zimmermann J, Gao J, Brueggen J, Capraro HG, Cozens R, Evans DB, Fabbro D, Furet P, Porta DG, Liebetanz J, Martiny-Baron G, Ruetz S, Hofmann F (2004) In vivo antitumor activity of NVP-AEW541-A novel, potent, and selective inhibitor of the IGF-IR kinase. Cancer Cell 5: $231-239$

Girnita A, Girnita L, del Prete F, Bartolazzi A, Larsson O, Axelson M (2004) Cyclolignans as inhibitors of the insulin-like growth factor-1 receptor and malignant cell growth. Cancer Res 64: 236-242

Hellstrom A, Perruzzi C, Ju M, Engstrom E, Hard AL, Liu JL, AlbertssonWikland K, Carlsson B, Niklasson A, Sjodell L, LeRoith D, Senger DR, Smith LE (2001) Low IGF-I suppresses VEGF-survival signaling in retinal
Specifically inhibiting the IGF-IR tyrosine kinase has been proved to be a successful approach for other small molecules as well (Garcia-Echeverria et al, 2004; Mitsiades et al, 2004; WarshamanaGreene et al, 2004).

In conclusion, we have demonstrated that IGF system is essential for proliferation and survival in a KS cell line, which has characteristics similar to the human disease and we suggest that targeting the IGF-IR could represent a powerful candidate for KS therapy. endothelial cells: direct correlation with clinical retinopathy of prematurity. Proc Natl Acad Sci USA 98: 5804-5808

Kaaya E, Castanos-Velez E, Heiden T, Ekman M, Catrina AI, Kitinya J, Andersson L, Biberfeld P (2000) Proliferation and apoptosis in the evolution of endemic and acquired immunodeficiency syndrome-related Kaposi's sarcoma. Med Oncol 17: 325-332

Khandwala HM, McCutcheon IE, Flyvbjerg A, Friend KE (2000) The effects of insulin-like growth factors on tumorigenesis and neoplastic growth. Endocr Rev 21: 215-244

LeRoith D, Helman L (2004) The new kid on the block(ade) of the IGF-1 receptor. Cancer Cell 5: 201-202

LeRoith D, Roberts Jr CT (2003) The insulin-like growth factor system and cancer. Cancer Lett 195: 127-137

Masood R, Cai J, Zheng T, Smith DL, Naidu Y, Gill PS (1997) Vascular endothelial growth factor/vascular permeability factor is an autocrine growth factor for AIDS-Kaposi sarcoma. Proc Natl Acad Sci USA 94: 979-984

Mitsiades CS, Mitsiades NS, McMullan CJ, Poulaki V, Shringarpure R, Akiyama M, Hideshima T, Chauhan D, Joseph M, Libermann TA, GarciaEcheverria C, Pearson MA, Hofmann F, Anderson KC, Kung AL (2004) Inhibition of the insulin-like growth factor receptor-1 tyrosine kinase activity as a therapeutic strategy for multiple myeloma, other hematologic malignancies, and solid tumors. Cancer Cell 5: 221-230

Mori S, Murakami-Mori K, Jewett A, Nakamura S, Bonavida B (1996) Resistance of AIDS-associated Kaposi's sarcoma cells to Fas-mediated apoptosis. Cancer Res 56: $1874-1879$

Pandini G, Frasca F, Mineo R, Sciacca L, Vigneri R, Belfiore A (2002) Insulin/insulin-like growth factor I hybrid receptors have different biological characteristics depending on the insulin receptor isoform involved. J Biol Chem 277: 39684-39695

Parkin DM, Wabinga H, Nambooze S, Wabwire-Mangen F (1999) AIDSrelated cancers in Africa: maturation of the epidemic in Uganda. AIDS 13: $2563-2570$

Samaniego F, Young D, Grimes C, Prospero V, Christofidou-Solomidou M, DeLisser HM, Prakash O, Sahin AA, Wang S (2002) Vascular endothelial growth factor and Kaposi's sarcoma cells in human skin grafts. Cell Growth Differ 13: 387-395

Shawver LK, Slamon D, Ullrich A (2002) Smart drugs: tyrosine kinase inhibitors in cancer therapy. Cancer Cell 1: 117-123

Skobe M, Brown LF, Tognazzi K, Ganju RK, Dezube BJ, Alitalo K, Detmar M (1999) Vascular endothelial growth factor-C (VEGF-C) and its receptors KDR and flt-4 are expressed in AIDS-associated Kaposi's sarcoma. J Invest Dermatol 113: $1047-1053$

Smith LE, Shen W, Perruzzi C, Soker S, Kinose F, Xu X, Robinson G, Driver S, Bischoff J, Zhang B, Schaeffer JM, Senger DR (1999) Regulation of vascular endothelial growth factor-dependent retinal neovascularization by insulin-like growth factor-1 receptor. Nat Med 5: 1390-1395

Surmacz E (2003) Growth factor receptors as therapeutic targets: strategies to inhibit the insulin-like growth factor I receptor. Oncogene 22: 65896597

van Gijlswijk RP, Gijlswijk-Janssen DJ, Raap AK, Daha MR, Tanke HJ (1996) Enzyme-labelled antibody-avidin conjugates: new flexible and sensitive immunochemical reagents. J Immunol Methods 189: 117-127

Warshamana-Greene GS, Litz J, Buchdunger E, Hofmann F, GarciaEcheverria C, Krystal GW (2004) The insulin-like growth factor-I (IGF-I) receptor kinase inhibitor NVP-ADW742, in combination with STI571, delineates a spectrum of dependence of small cell lung cancer on IGF-I and stem cell factor signaling. Mol Cancer Ther 3: 527-535

Weich HA, Salahuddin SZ, Gill P, Nakamura S, Gallo RC, Folkmann J (1991) AIDS-associated Kaposi's sarcoma-derived cells in long-term 
culture express and synthesize smooth muscle alpha-actin. Am J Pathol 139: $1251-1258$

Wu Y, Cui K, Miyoshi K, Hennighausen L, Green JE, Setser J, LeRoith D, Yakar S (2003) Reduced circulating insulin-like growth factor I levels delay the onset of chemically and genetically induced mammary tumors. Cancer Res 63: 4384-4388
Yakar S, Wu Y, Setser J, Rosen CJ (2002) The role of circulating IGF-I: lessons from human and animal models. Endocrine 19: $239-248$

Zhang L, Zhou W, Velculescu VE, Kern SE, Hruban RH, Hamilton SR, Vogelstein B, Kinzler KW (1997) Gene expression profiles in normal and cancer cells. Science 276: $1268-1272$ 